\title{
Antagonism of Pseudomonas fluorescens from plant roots to Rigidoporus lignosus pathogen of rubber white roots in vitro
}

\author{
NURHAYATI DAMIRI ${ }^{1, \boldsymbol{v}}$, MULAWARMAN ${ }^{1}$, RAHIM S. EFFENDI ${ }^{2}$ \\ ${ }^{1}$ Department of Plant Pests and Diseases, Faculty of Agricultural, Universitas Sriwijaya. Indralaya, Ogan Ilir 30862, South Sumatra, Indonesia. \\ Tel.: +62-896-3874-9695, "email: nurhayati@fp.unsri.ac.id. \\ ${ }^{2}$ Sekolah Tinggi Ilmu Kesehatan Bina Husada Palembang. Jl. Syech A. Somad No. 28, Palembang 30131, South Sumatra, Indonesia
}

Manuscript received: 2 February 2019. Revision accepted: 8 May 2019.

\begin{abstract}
Damiri N, Mulawarman, Effendi RS. 2019. Antagonism of Pseudomonas fluorescens from plant roots to Rigidoporus lignosus pathogen of rubber white roots in vitro. Biodiversitas 20: 1549-1554. Indonesia's rubber productivity is still relatively low. This low productivity of rubber can be caused by many factors such as the attack of Rigidoporus lignosus. This study aims to explore antagonistic bacteria from the plant roots and test their antagonism ability to R. lignosus at the laboratory level. This research was conducted at the Laboratory at the Faculty of Agriculture, Sriwijaya University, Indralaya Ogan Ilir District, South Sumatra, Indonesia. Corporate and bacterial isolations are carried out by serial dilution method. In-vitro testing of antagonistic bacteria was carried out using the dualculture technique method on sterile PDA media by direct opposition between $R$. lignosus culture and antagonistic bacteria explored. Results of the study showed that a number of bacterial isolates existed there, namely 11 bacterial isolates belonging to Pseudomonas fluorescens, four from turmeric roots, three from the roots of rubber seedlings, two from galangal roots and two from the roots of yielding rubber plants. $P$. fluorescens from roots of turmeric, rubber seedlings, rubber, and galangal was able and had the potential to be developed as biopesticide to control $R$. lignosus. The best isolate in suppressing the growth and development of $R$. ligonosus is $P$. fluorescens isolates from the roots of turmeric and those of rubber seedlings (isolates of $\mathrm{C}, \mathrm{B}$, and $\mathrm{G}$ ).
\end{abstract}

Keywords: Antagonism, P. fluorescens, R. ligonosus, roots, rubber

\section{INTRODUCTION}

The area of rubber plantations in Indonesia reaches 3.4 million hectares, in which 2.9 million hectares or $85 \%$ is smallholder plantation. The rests are large state-owned plantations and large private-owned plantations, with production of up to 3,012,254 tons and productivity of $1073 \mathrm{~kg}$ dry rubber ha- $^{1}$ (Directorate General of Plantations, 2015). Indonesia's rubber productivity is still relatively low when compared to other rubber producing countries. This low productivity of rubber can be caused by many factors, one of which is the attack of white root disease. White root fungus disease caused by Rigidoporus lignosus is an important disease in rubber plants. Disease can attack rubber plants both in nurseries, immaturity or yielding plants. White root disease can result in the death of many rubber plants, especially rubber plants with the age of 2 to 6 years.

The attack occurs at the rubber root and causes root damage. At the root of rubber plant with white root disease, there are rather thick white threads that are known as rhizomorph (Fairuzah et al. 2014). Secondary symptoms of attack on rubber leaves are yellowing leaves with the folded in edges or edges. At further attack, the leaves will fall and the tip of the branch dies. Sometimes young leaves, flowers, and fruit may form too early. Transmission of white root fungi can occur through the intersection of healthy rubber roots with the remnants of roots and stumps of sick old trees or due to wind gusts that carry these mold spores which then fall on the roots of plants. They will grow and form colonies and then propagate to stump branch roots and move to nearby plant roots by linking the roots. White root fungus is a soil-borne disease that can survive as a source of infection for many years, so it is not easy to control (Amaria and Edi 2014; Manurung et al. 2014).

The attack of white root fungi can result in a loss of rubber yield between 3-5\% with a loss of IDR 300 billion annually (Situmorang 2004; Industrial Crops and Refresher Research Institute, 2014). The use of biological agents as pathogenic controllers in plants has become a worldwide concern. This is due to the ability of biological agents to suppress the development of diseases in plants, also because the use of biological agents does not cause negative impacts on the environment. Disease control using biological agents such as bacteria or fungi has the potential to prevent and suppress the development of soil-borne pathogens. Besides that, biological agents also increase disease resistance. Generally, the biological agents in the rhizosphere are more adaptable and well developed so that they have a great opportunity to be developed as biopesticides (Malmierca et al. 2012). Several types of rhizobacteria are used as biological agents to control pathogens such as Bacillus sp. and Pseudomonas fluorescens (Chrisnawati, Nasrun and Triwidodo 2009; Manjunatha et al. 2012; Toua et al. 2013).

Pseudomonas spp. is one of the biological agents that has the potential to be developed as a biopesticide. $P$. fluorescens can control several pathogens including 
Botrytis cinerea on strawberries, $R$. solanacearum on peanuts, patchouli and Xanthomonas axonopodis (Haggag and Soud 2012; Manjunatha, 2012; Nawangsih et al. 2012). Many types of Pseudomonas spp. are capable of producing salicylic acid compounds or phenoloxidase and phenylalanine ammonia lyase (PAL) compounds which can induce resistance to pathogens in plants (Fallahzeda et al, 2009). This study aims to explore antagonistic bacteria from the roots of turmeric (Curcuma longa), galangal (Alpinia galanga) and rubber (Hevea brasiliensis) and to test its antagonism ability of $R$. lignosus at the laboratory level. Novelty from the results of this study includes: providing information on the database of knowledge about the potential of $P$. fluorescens from turmeric plant roots, galangal and rubber as biological agents to control $R$. lignosus white root pathogen in rubber plants.

\section{MATERIALS AND METHODS}

This research was conducted at the Laboratory of Phytopathology Department of Plant Pests and Diseases Faculty of Agriculture, Sriwijaya University, Indralaya Ogan Ilir District, South Sumatra, Indonesia.

\section{Exploration and isolation of antagonistic bacteria.}

Corporate and bacterial isolations were carried out by serial dilution method. The roots of the plant used in this study were the roots of the turmeric plant, the galangal plant, and the rubber plant. As much as 1 gram of each root was cut down into pieces and washed with running water separately, and then air dried. The pieces were then ground using a sterile mortal until smooth, then put into a test tube which has been filled with $9 \mathrm{ml}$ of sterile aquadest. The mixture is shaken until it is suspended evenly and homogeneously using a shaker with a speed of $150 \mathrm{rpm}$ for 30 minutes. The suspension is further diluted to a level of $10^{-3}$ dilution. Then $0.1 \mathrm{ml}$ is taken to be grown in Petri dishes which were filled with sterile King's B media (KBA).

Incubation is carried out for two to three days at room temperature. Morphological characterization and the observation by morphology and physiology tests to determine bacterial genera and species were carried out according to Kerr's method (1980) and Schaad et al. 's method (2001). After three days, a growing microbial colony was observed under ultraviolet light to examine the yellowish green scattered colonies. This work was to see the antagonistic bacteria included in the $P$. fluorescens group. Selected bacterial isolates were rejuvenated on sterile King's B medium and incubated for two to three days at room temperature.

\section{Rigidoporus lignosus isolation propagation.}

Rigidoporus lignosus isolates were obtained from the Sembawa Research Institute. White root fungus isolates were then propagated using PDA media and then incubated for seven days to be used at a later stage.

\section{Antagonism test for Pseudomonas fluorescens bacteria.}

In-vitro testing of antagonistic bacteria was carried out using the dual-culture technique method on sterile PDA media by direct opposition between $R$. lignosus culture and antagonistic bacteria explored. Then the Petri dishes were incubated at room temperature. The test was conducted using a completely randomized design with 11 treatments namely $P$. fluorescens isolates which were obtained previously (isolates A, B, C, D, E, F, G, H, I, J, K, and control). Each treatment consists of 4 replications. All of the above work was done aseptically in laminar airflow. The parameters observed in this test were the percentage of antagonistic bacterial inhibitory power and the weight of $R$. lignosus biomass. $P$. fluorescens against $R$. lignosus inhibitory power was calculated by the formula:

Inhibition percentage $=R o-\frac{R 1+R 2}{2} \times 100 \%$

Where:

$\mathrm{R}_{0}$ : Finger growth of $R$. lignosus control (cm)

$\mathrm{R}_{1} \& \mathrm{R}_{2}$ : Fingers of $R$. lignosus treatment $(\mathrm{cm})$

The weight of biomass of White root fungus was calculated by dredging all parts of fungal mycelia grown on PDA media, and putting them into a test tube filled with 10 $\mathrm{ml}$ of distilled water and then dishing them at $150 \mathrm{rpm}$ for 15 minutes and filtering them with filter paper, and then drying them and weighing them. The data were analyzed using analysis of variance (ANOVA), with the Duncan's Multiple Range Test (DMRT) comparison among means (Gomez and Gomes 1984).

\section{RESULTS AND DISCUSSION}

The results of isolation of bacteria from the roots of rubber plants, the roots of rubber seedlings planted in polybags, roots of turmeric, root of galangal showed the obtained 40 isolate samples. Of the 40 samples observed, 11 bacterial isolates belonging to $P$. fluorescens were found, namely four isolates derived from turmeric roots, three isolates from the roots of rubber seedlings, two isolates from galangal roots and two isolates derived from the roots of yielding rubber plants from Palembang and Indralaya city. The morphology and antagonism abilities of each isolate are presented in Figure 1 and Table 1. The results of the antagonistic test of $11 P$. fluorescens bacterial isolates from the roots of turmeric, rubber seedlings, rubber, and galangal showed a very significant difference, and further tests of the antagonistic ability of bacteria from rubber roots were presented in Table 2 and Figure 2. 
Table 1. Morphology of Pseudomonas fluorescens bacteria from roots of rubber, galangal, and turmeric

\begin{tabular}{|c|c|c|c|c|c|c|}
\hline \multirow{2}{*}{$\begin{array}{l}\text { P. fluorescens } \\
\text { Isolate code }\end{array}$} & \multicolumn{6}{|c|}{ Colony morphology } \\
\hline & Form & Colour & Edge & Elevation & Margin & Size \\
\hline A & Irregular & Milky white & Slippery & Raised & Lobate & Medium \\
\hline B & Circular & Milky white & Slippery & Convex & Lobate & Large \\
\hline $\mathrm{C}$ & Irregular & Milky white & Screw up & Umbonate & Cerrate & Small \\
\hline $\mathrm{D}$ & Irregular & Milky white & Slippery & Convex & Entire & Pinpoint \\
\hline $\mathrm{E}$ & Circular & Greenish yellow & Slippery & Convex & Undulate & Small \\
\hline $\mathrm{F}$ & Circular & Brownish white & Slippery & Convex & Undulate & Small \\
\hline G & Circular & Milky white & Screw up & Convex & Lobate & Medium \\
\hline $\mathrm{H}$ & Irregular & Milky white & Screw up & Convex & Lobate & Large \\
\hline I & Irregular & Milky brownish white & Screw up & Convex & Lobate & Small \\
\hline J & Irregular & Brownish white & Slippery & Umbonate & Entire & Large \\
\hline $\mathrm{K}$ & Irregular & $\begin{array}{l}\text { Milky white Milky } \\
\text { white }\end{array}$ & Screw up & Convex & Lobate & Medium \\
\hline
\end{tabular}

Note: isolates A, B, C and D are P. fluorescens from the roots of turmeric; isolate E, F, and $\mathrm{G}$ from roots rubber seedlings, $\mathrm{H}$ isolates from Palembang's yielding rubber roots, isolates I and J origin of galangal roots and isolates K from Indralaya's yielding rubber roots

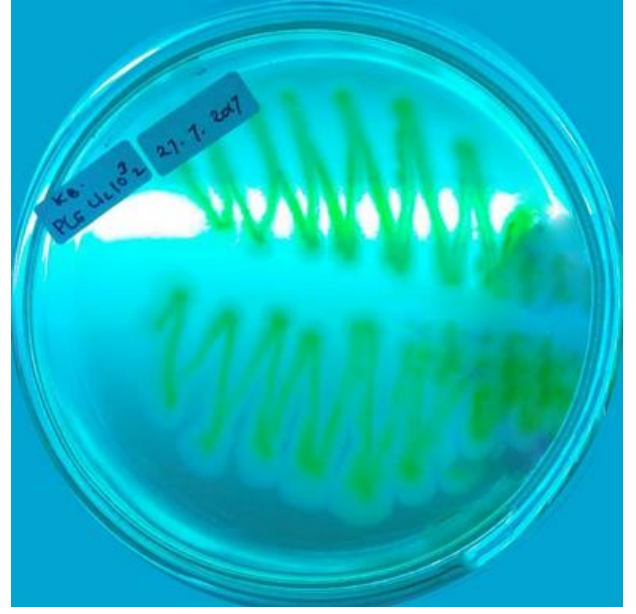

Figure 1. Isolate Pseudomonas fluorescens which glows under the light ultraviolet

Table 2. The inhibitory power of Pseudomonas fluorescens isolates on growth of Rigidoporus lignosus, white root pathogen in rubber plants

\begin{tabular}{cc}
\hline $\begin{array}{c}\text { Pseudomonas fluorescens } \\
\text { isolate code }\end{array}$ & $\begin{array}{c}\text { Inhibition percentage } \\
(\%)\end{array}$ \\
C & $88.91 \mathrm{a}$ \\
I & $85.34 \mathrm{a}$ \\
G & $84.84 \mathrm{a}$ \\
A & $83.13 \mathrm{a}$ \\
D & $80.60 \mathrm{a}$ \\
B & $80.20 \mathrm{a}$ \\
E & $79.78 \mathrm{a}$ \\
F & $73.58 \mathrm{ab}$ \\
J & $59.87 \mathrm{bc}$ \\
K & $49.58 \mathrm{c}$ \\
H & $29.37 \mathrm{~d}$ \\
Control & $0 \mathrm{e}$ \\
\hline
\end{tabular}

Note: The numbers followed by the same letter are not significantly different at $\mathrm{p} \leq 0.05$ DMRT. Isolates $\mathrm{A}, \mathrm{B}, \mathrm{C}$ and $\mathrm{D}$ from the roots of turmeric; isolate $\mathrm{E}, \mathrm{F}$, and $\mathrm{G}$ from roots rubber seedlings, $\mathrm{H}$ isolates from Palembang's yielding rubber roots, isolates $\mathrm{I}$ and $\mathbf{J}$ origin of galangal roots and isolates $\mathrm{K}$ from Indralaya's yielding rubber roots.
Table 2 showed that all isolates (A, B, C, D, E, F, G, H, I, J, K) showed good antagonistic ability in suppressing the development of white root fungi caused by $R$. lignosus and significantly different from controls. Isolate $\mathrm{C}$ showed the best ability to suppress the development of $R$. lignosus with a percentage of suppression reaching 88.91 percent, followed by isolates I, G, A, D, B, E and F. The eight isolates were not significantly different from each other but significantly different from isolates of $\mathrm{J}, \mathrm{K}, \mathrm{H}$, and control.

Pseudomonas spp. is a root-colonizing bacterium and induces resistance to plants and antagonistic bacteria through antibiosis and competition to control various plant diseases. P. fluorescens can produce siderophore including pyoverdine, salicylic acid and indole acetate which can induce plant resistance to pathogens (Defago et al. 1990; Meyer et al. 2012). P. fluorescens reportedly can also directly inhibit pathogens by producing antibiotics such as pyoluteorin 2.4-diacetyl phloroglucinol and cyanide acid antibiotics, as produced by $P$. fluorescens which can suppress the development of bacterial wilt disease caused by Ralstonia solanacearum in tomatoes, potatoes, tobacco, bananas and ginger (Nasrun et al. 2005; Aspiras and Cruz 1985). In addition, P. fluorescens is also known as a bacterial plant growth promoting Rhizobacteria (PGPR) because it is able to dissolve phosphate and produce plant growth hormones such as IAA which can increase plant growth. P. fluorescens is capable of colonizing and adapting well to plant roots to synthesize metabolism which is able to inhibit growth and pathogen activity or induce systemic resistance to pathogens.

It was reported by Grata (2016), that $P$. fluorescens is able to suppress the growth of Fusarium oxysporum mycelium because it is capable of producing secondary metabolic compounds that affect and inhibit fungal growth. The average Fusarium oxysporum growth rate index treated with P. fluorescens for 48 hours was inhibited at a rate of around 33.2-49.33\%. The level of antifungal activity of $P$. fluorescens varies greatly, largely depending on the ability of secretion of secondary metabolism, especially lytic and antibiotic enzymes. Production of lytic enzymes such as chitinase, glucanase, pectinase; salicylic acid; iron 
(Fe) -chelating siderophores; indole-3-acetic acid (IAA), secondary metabolic compounds and antibiotics are likely a mechanism that plays an important role in the antifungal activity of Pseudomonas (Toua et al. 2013). P. fluorescens is able to increase phenolic compounds such as tannins, saponins, and glycosides in plant tissues so that it is expected to increase plant resistance to pathogens. As proven by Soesanto et al. (2010), the application of $P$. fluorescens P60 on tomato plants can suppress fusarium wilt infection and pathogen populations, and increase plant growth and tomato fruit production.

According to Nasrun and Nurmansyah (2015), $P$. fluorescens and Bacillus sp. are effective in controlling white root disease in endemic areas. It was reported by Soesanto et al. (2010) that P. fluorescens can increase phenolic compounds such as tannins, saponins, and glucosides in colonized plant tissues, suppress the amount of fusarium density of pathogens withered in tomatoes, suppress infection rates and reduce the intensity of attacks. The application of this agent can also increase plant height, root dry weight, and tomato weight. Damiri (2017) states that $P$. fluorescens is able to inhibit the growth of Peronospora parasitica pathogen downy mildew in caisin. $P$. fluorescens can protect aloe plants against fusarium disease and also increase plant growth (Wahyuni et al. 2015). P. fluorescens is one of the microbes that has been widely used as biological agents and is also known as Plant Growth Promoting Rhizobacteria (PGPR). P. fluorescens can produce antibiotics, siderophore and is able to colonize plant roots and induce resistance (Soesanto and Rahayuniati 2009).

Analysis of the diversity of the effect of $P$. fluorescens bacteria on the weight of $R$. lignosus biomass shows a very significant effect. Further test is presented in Table 3. All treatments with $P$. fluorescens isolate were able to reduce the weight of $R$. lignosus biomass and significantly different from the control. Isolate $\mathrm{G}$ showed the best effect followed by $P$. fluorescens isolate $\mathrm{C}$ and $\mathrm{B}$. The ability of
P. fluorescens isolate $\mathrm{G}, \mathrm{C}$, and B to suppress the development and weight of biomass $\mathrm{R}$. white lignosus pathogen fungal disease in rubber plants is thought to be due to the ability of this bacterium to produce toxins and antibiotics against these pathogens. In addition, the isolate $\mathrm{G}$ which is the best isolate in suppressing the weight of biomass, $R$. lignosus, is an isolate obtained from the root of the rubber plant so that it is likely more stable and stronger in its antagonistic ability.

Pseudomonas fluorescens is a root-colonizing bacterium and is able to produce salicylic acid and phytoalexin which can induce plant resistance to pathogens. Salicylic acid can induce soybean resistance to the attack of soybean stunt virus (SSV). Besides that, it was reported that these bacteria were also able to produce phenoloxidase and phenyl ammonia lyase which could induce plant resistance to Xanthomonas campestris pv. malvacearum attack (Fallahzadeh et al. 2009; Ardebili et al. 2011; Khalimi and Suparta 2011). Biological control activities can occur in pathogenic germination and mycelium growth inhibitions such as $R$. microporus (Thangavelu and Gopi 2015). P. fluorescens produces several metabolic secondary antimicrobial agents. In addition, these bacteria are also able to produce cyanide / $\mathrm{HCN}$ acids and antibiotics such as pyrrolnitrin, pyoluteorin, biosurfactant and 2.4-diacetyl phloroglucinol which can suppress pathogen growth or kill pathogens such as fungi. Siderofor produced by $P$. fluorescens is known to limit the use of iron compounds needed by most pathogens in the soil. HCN produced by Rhizobacteria can inhibit the growth of pathogens by breaking down the walls of pathogenic cells. This compound is an inhibitor potential for cytochrome $\mathrm{c}$ oxidase and several other metalloenzymes so that the damage to the cell wall will result in the death of the pathogen. $P$. fluorescens has the potential to be developed as a biopesticide (Manidipa, Dutta and Venkata 2013; Salamiah 2015; Sriyanti et al. 2015).

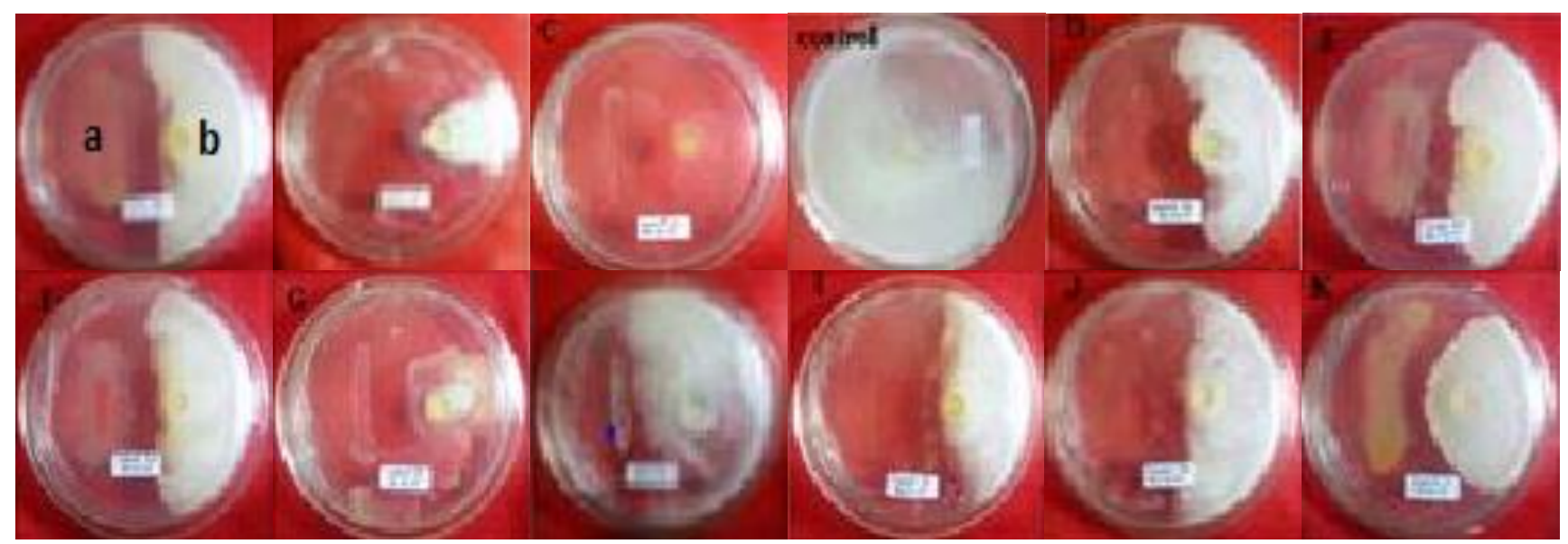

Figure 2. Antagonistic test of Pseudomonas fluorescens against Rigidoporus lignosus pathogen white root fungus on rubber plants. a. shows $P$. fluorescens, b. shows R. lignosus 
Table 3. Effect of Pseudomonas fluorescens isolates on the weight of Rigidoporus lignosus, biomass root pathogens, in rubber plants

\begin{tabular}{cc}
\hline $\begin{array}{c}\text { Pseudomonas } \\
\text { fluorescens isolate code }\end{array}$ & $\begin{array}{c}\text { Average biomass weight of } \\
\text { Rigidoporus lignosus }(\mathrm{g})\end{array}$ \\
\hline Control & $0.412 \mathrm{a}$ \\
H & $0.342 \mathrm{~b}$ \\
F & $0.340 \mathrm{~b}$ \\
K & $0.333 \mathrm{~b}$ \\
J & $0.330 \mathrm{~b}$ \\
A & $0.328 \mathrm{~b}$ \\
D & $0.327 \mathrm{~b}$ \\
I & $0.327 \mathrm{~b}$ \\
E & $0.324 \mathrm{~b}$ \\
B & $0.321 \mathrm{~b}$ \\
C & $0.321 \mathrm{~b}$ \\
G & $0.315 \mathrm{~b}$ \\
\hline
\end{tabular}

Note: The numbers followed by the same letter are not significantly different at $\mathrm{p} \leq 0.05 \mathrm{DMRT}$. Isolates $\mathrm{A}, \mathrm{B}, \mathrm{C}$ and $\mathrm{D}$ from the roots of turmeric; isolate $\mathrm{E}, \mathrm{F}$ and $\mathrm{G}$ from roots of rubber seedlings, $\mathrm{H}$ isolates from Palembang's yielding rubber roots, isolates $\mathrm{I}$ and $\mathrm{J}$ origin of galangal roots and isolates $\mathrm{K}$ from Indralaya's yielding rubber roots.

Generally, antagonistic bacteria have several mechanisms in inhibiting pathogenic fungi. The antagonisms bacteria can produce bioactive compounds that damage the structural components of pathogenic fungi. Damage to the structural components of fungi occurs by hydrolytic enzymes such as chitinase produced by chitinolytic bacteria. This bioactive compounds also can affect the permeability of fungal cell membranes so that the transport of substances needed for metabolism is disrupted. The compounds produced by bacteria can function as inhibitors of an enzyme in the fungus. If the fungus enzyme plays an important role in metabolism, the enzymatic activity of the cell will be disrupted, resulting in depressed fungal growth. In addition, the compounds also can inhibit fungal protein synthesis. The disturbed Protein synthesis causes fungi to lack protein so that their growth is inhibited (Ferniah et al. 2004). Pseudomonas spp has been extensively studied as a biological control agent and all of them secrete antibiotic compounds such as phenazine derivatives, pyoluteorin, pyrrolnitrin, viscosinamide and 2,4-diacetyl phloroglucinol (Michel et al. 2005). $P$. fluorescens produces pyoluteorin antibiotics (Nasrun and Nurmansyah 2015) which can inhibit the growth of pathogenic Rhizoctonia solani, Alternaria sp. and Verticillium dahlia. Observation of interaction test under a microscope with an enlargement of $80 \mathrm{x}$, it was seen that the fungus hyphae of $R$. lignosus had cone. This purification is triggered by the presence of chitinase enzymes which are capable of degrading and capable of destroying the cell wall of $R$. lignosus.

In conclusion, from the results of this study, it can be concluded that: (i) P. fluorescens from roots of turmeric, rubber seedlings, yielding rubber and galangal is able and has the potential to be developed as a biopesticide to control $R$. lignosus, (ii) The best three isolates in suppressing the growth and development of $R$. ligonosus are $P$. fluorescens isolates from the roots of turmeric and root of rubber seedlings (C, B, and $\mathrm{G})$.

\section{ACKNOWLEDGEMENTS}

This study was partly results of the Profession Research Funded by the Research Institute of Sriwijaya University, Ministry of Research, Technology and Higher Education, Republic of Indonesia. The authors would like to address their appreciation to editor-in-chief and editors of this journal for their help and guidance and unanimous reviewers for the corrections for improving quality of the article.

\section{REFERENCES}

Amaria W, Edi W. 2014. Effect of application time and kind of Trichoderma on white root disease of rubber seedling. J Ind Beverage Crops 1 (2): 79-86.

Ardebili ZO, Ardebil NO, Hamdi SMM. 2011. Physiological effect of Pseudomonas fluorescens $\mathrm{CHAO}$ on tomato (Lycopersicum esculentum Mill) plants and its possible impact on Fusarium oxysporum f. sp lycopersici. Aust J Crop Sci 5 (12): 1631-1638.

Aspiras RB, De la Crus AR. 1985. Potential biological control of bacterial wilt in tomato and potato with Bacillus polymyxa FU6 and Pseudomonas flourescens. In: Persley GJ (ed.). Bacterial wilt disease in Asian and South Pacific. Proc. Int. Workshop at PCARRDAustralian Centre International Agricultural Reseach (ACIAR), Los Banos 13: 89-92.

Chrisnawati, Nasrun, Triwidodo A. 2009. Control of patchouli bacterial wilt using Bacillus spp. and Pseudomonas fluorescens. J Indon Ind Res 15 (3): 116-123.

Damiri N, Mulawarman, Umayah A, Agustin SE, Rahmiyah M. 2017. Effect of Pseudomonas spp. on infection of Peronospora parasitica (Pers. Fr), the pathogen of downy on Chinese cabbage. International Symposium on Food and Agro-biodiversity (ISFA). IOP Conf Ser Earth Environ Sci 102: 012065. DOI: 10.1088/17551315/102/1/012065

Defago G, Berling CH, Burger U, Hass D, Kahr G, Keel C, Voisard C, Wirthner P, Wuthrich B. 1990. Suppression of black root of tobacco and other root diseases by strains of Pseudomonas fluorescens: potential applications and mechanisms, In: Hornby, D. (Ed), Biological Control of Soilborne Plant Pathogens. CAB International, Wallingford, UK

Directorate General of Plantations, Ministry of Agriculture. 2015. Annual report of Plantation Directorate General year of 2014. Jakarta. http://dirjenbun.pertanian.go.id on $18^{\text {th }}$ July 2018.

Fairuzah Z, Dalimunthe CL, Karyudi, Suryaman S, Widhayati W E. 2014. Effectiveness of several antagonistic fungi (Trichoderma sp.) In endohevea biofungicides on white root fungus disease (Rigidoporus microporus) in the field. Rubb Res J 32 (2): 122-128.

Fallahzadeh V, Ahmadzadeh M, Marefat A, Ghazanfary K. 2009. Application of rhizobacteria for induction of systemic resistance to bacterial blight of cotton caused by Xanthomonas campestris pv. malvacearum using Pseudomonas fluorescens of rhizosphere. J Plant Protec Res 49 (4): 416-420. DOI: 10.2478/v10045-009-0066-5.

Gomez KA, Gomez AA. 1984. Statistical Procedure of Agricultural Research. 2nd ed. Wiley-Intersci., New York.

Grata K. 2016. Biocontrol activities of Pseudomonas fluorescens against asparagus pathogen. Proc of ECO pole 10 (1): 27-32. DOI: 10.2429/proc.2016.10 (1)003.

Haggag WM, Soud MA. 2012. Production and optimization of Pseudomonas flourecens biomass and metabolites for biocontrol of strawberry grey mould. Amer J Plant Sci 3: 836-845.

Industrial Crops and Refresher Research Institute. 2014. White root fungus a dangerous disease in rubber plantations. Research and Development Center for Agriculture, Agricultural Research and Development Agency Ministry of Agriculture, Jakarta. http://balitri.litbang.pertanian.go.id [17 th June 2018]. 
Kerr A. 1980. Bacteria and mycoplasma as plant parasites. In: Brown JF (ed.). A Course Manual in Plant Protection. Australia Vice Chancellors Committee, Brisbane.

Khalimi K, Suparta DN. 2011. Induction of plant resistance against soybean stunt virus using some formulation of Pseudomonas aeruginosa. J ISSAAS 17 (1): 98-105.

Manidipa R, Duta SG, Venkata RCH. 2013. Pseudomonads: Potentia biocontrol agents of rice disease. Res J Agric For Sci 9: 19-25.

Malmierca MG, Cardosa RE, Alexander NJ, McComick SP, Hermosa R, Monte E, Gutierrez S. 2012. Title: Involvement of Trichoderma trichothecenes in the biocontrol activity and in the induction of plant defense-related genes. Appl Environ Microb 78 (14): 456-486.

Manjunatha H, Naik MK, Patil MB, Lokesha R. Vasudevan SN. 2012 Isolation and characterization of native Pseudomonas fluorecens and antagonistic activity against major plant pathogens. Karnataka J Agric Sci 25 (3): 346-349.

Manurung L, Lahmuddin L, Marheni, Cici ID. 2014. Testing various type of active ingredients against White Root Fungus (WRF) disease (Rigidoporus microporus (Swartz: Fr.) in areas without tillage 1: 168178.

Meyer KM, Leveau JHJ. 2012. Microbiology of the phyllosphere: a playground for testing ecological concepts. Oecologia 168 (3): 621 629.

Nasrun, Christanti, Arwiyanto T, Mariska. 2005. The controlling of Nilam wilt disease using Pseudomonas fluorescens. J Ind Crops Res 11 (1): $19-24$.

Nasrun and Nurmansyah. 2015. Potency of rhizobacteria and botanical fungicides to control white root fungus disease in rubber plant. J Ind Beverage Crops 2 (2): 61-68.

Nawangsih AA, Aditya R, Tjahjono, Negishi, Suyama K. 2012. Bioefficacy and characterization of Plant Growth Promoting Bacteria to control the bacterial wilt disease of peanut in Indonesia. J. ISSAAS 8 (1): $185-192$
Salmiah, Wahdah R. 2015. Utilization of Plant Growth Promoting Rhizobacteria (PGPR) in tungro disease control in local rice in South Kalimantan. Pros Sem Nas Masy Biodiv Indon 1 (6): 1448-1456. [Indonesian]

Situmorang A. 2004. Status and management of controlling white root disease in rubber plantations. In: Situmorang A, Budiman A., Suryanningtyas H, Thomas M. Lasminingsih, Gunawan (eds). Technical Meeting of Rubber Plant Management Strategies to Maintain Production Potential to Support Indonesia's Rubber Industry in 2020. Sembawa Rubber Research, Palembang.

Soesanto L, Rahayuniati RF. 2009. Induced resistance of Raja cultivar banana seedling to fusarium wilt by applying antagonistic bacterial extract. J Trop Plant Pests Dis 9 (2): 130-140.

Soesanto L, Mugiastuti E and Rahayuniati RF. 2010. Antagonistic mechanisms study of Pseudomonas flourescens P60 on Fusarium oxysporum f.sp. lycopersici of tomato in vivo. J HPT Trop 10 (2): $108-115$.

Sriyanti, Gede NL, Suprapta DN, Suada IK. 2015. Test the effectiveness of rhizobacteria in inhibiting the growth of fungi Colletotrichum spp. the cause of anthracnose in red chili (Capsicum annuum L). E-J Agrotechnol Trop 4 (1): 53-65.

Schaad NW, Jones JB, Chun W. 2001. Laboratory Guide for Identification of Plant Pathogenic Bacteria. 3rd ed. St Paul: APS Press.

Thangavelu R, Gopi M. 2015. Field suppression of Fusarium wilt disease in banana by combined application of native endophytic and rhizospheric bacterial isolates possessing multiple functions. Phytopathologia Mediterranea 54 (2): 241-252.

Toua D, Benchabane M, Bensaid F, Bakour R. 2013. Evaluation of Pseudomonas fluorescens for the biocontrol of Fusarium wilt in tomato and flax. Afr J Microbiol Res 7 (58): 5449-5458.

Wahyuni T, Damiri N, Mulawarman. 2015. Population dynamic of rhizobacteria and its potency as a biological control agent to control Fusarium disease in nursery of agarwood. Agrivita 37 (3): 276-283. 